\title{
Does working capital management affect the profitability of commercial banks: the case of Kosovo
}

\author{
Ibish Mazreku ${ }^{1}$, Fisnik Morina*2, Florentina Zeqaj ${ }^{3}$
}

\begin{abstract}
:
Purpose: This paper aims to analyze working capital and its impact on the profitability of commercial banks. The other objectives of this study are to analyze the factors that influence the profitability of commercial banks, to find out the relationship between profitability and working capital management. To achieve these research objectives, several research questions have been posited: How much does working capital affect the profitability of commercial banks? What are the relationships between bank profitability and bank size, debt ratio and current ratio? What are the other factors affecting the profitability of commercial banks?

Methodology: The empirical data to be used in this research are secondary data and will be based on annual reports of commercial banks and reports of the Central Bank of Kosovo. From these data, some indicators such as return on assets, current ratio, debt ratio and banks' size will be calculated. This research covers a period of 5 years and the data will be analyzed and interpreted through econometric models. In addition, to analyze the impact of working capital on the profitability of commercial banks in Kosovo, trend analysis will also be applied through the comparative method.

Findings: Based on the empirical results, we can conclude that bank size and the current ratio have positively affected the performance of commercial banks in Kosovo, whereas the debt ratio has had a negative effect. All the independent variables in relation to the dependent variable (ROA) are at the standard level of significance P-value $=0.05$.

Practical implications: Through this study we can recommend all commercial banks in Kosovo to invest much more in working capital, since financial investments in working capital affect the bank's profitability. This means that a high investment in the elements of working capital can lead to increased bank profitability, whereas its profitability decreases when investment in working capital is low.

Originality: This paper presents real and sustainable results with respect to the conclusions. The period analyzed (2013-2017) is a persuasive period for drawing competent conclusions and recommendations.
\end{abstract}

Keywords: working capital, debt ratio, current ratio, bank size, return on assets

JEL Classification: G2, G20, G21, G3, G32, D24

\section{Introduction}

Through the recent decades, there have been a significant number of research studies and articles investigating the importance of working capital management in relation to its effect on the profitability of companies. With an efficient working capital management, firms can reduce the level to which they rely on external financing and use the money issued for additional investments and to increase the firm's financial

\footnotetext{
| 'University "Haxhi Zeka" - Peja, Kosovo.

2University "Haxhi Zeka" - Peja, Kosovo, *corresponding author.

3University "Haxhi Zeka" - Peja, Kosovo.
} 
flexibility. Substantial research has been conducted in various parts of the world within different markets and industries to address the importance of efficient working capital management to maximize firm profitability and ultimately improve firm performance (Husaria, 2015, p. 8).

One of the key determinants of the survival and sustainable growth of a modern business is the effectiveness of the finance and accounting department. One area of accounting and finance that affects the efficient operations of business organizations in general is working capital management. Working capital management is described as the management of current assets and liabilities.

The concept of working capital management addresses a company's short-term capital management, which is an important component of corporate financial management, which directly impacts the profitability and liquidity of small and large firms. It is well recognized that small-scale industries contribute enormously to job opportunities, providing real sector progress and opening new business avenues for the development of a country (Mbawuni, Mbawuni, \& Nimako, 2016, p. 49).

To extend the explanation of the prominence of working capital, in essence: "firm management, working capital is a day-to-day activity that ensures the firm has sufficient resources to continue its operations and avoid costly interruptions. This includes a number of activities related to receiving and delivering a firm's cash". In addition, working capital management has fundamental implications for numerous reasons: "For one thing, the current assets of a typical manufacturing firm make up over half of its total assets" (Husaria, 2015, p. 9).

\section{Literature Review}

\subsection{Working capital as a concept}

Equity is a key factor that should be considered when assessing a bank's security and sustainability. Working capital management is defined as the management of current assets and current liabilities, as well as the financing of these current assets. In various scientific studies, working capital management has been found to have a significant impact on the profitability and liquidity of economic entities (Gill, Biger, \& Mathur, 2010, p. 2).

Working capital simply means the resources a firm has at its disposal to carry out its dayto-day operations. Successful management of working capital requires a well-designed policy and daily follow-up of this policy. Working capital management involves both the establishment of working capital policy and the application of this policy to day-to-day operations. Equally, it involves making appropriate investment decisions in cash, receivables and inventories, as well as the level and the combination of short-term financing ( Mandiefe, 2016, p. 1).

Working capital has several meanings, firms use it in various ways. Thus, the most important use of working capital is ensuring the continuous investment in the short-term assets with which a company must operate. Working capital refers to the investment in the current assets required to perform the operations of a business. Working capital also called floating capital or short-term capital is the capital needed to invest in current assets ( Mandiefe, 2016, p. 2). 


\subsection{Working capital management}

In the financial affairs of companies, working capital management is a very important factor, which has a direct positive effect on the profitability as well as in the liquidity of the company. The optimal level of liquidity guarantees a firm to meet its short-term debts and proper flow management can be promised by a profitable business. Liquidity demonstrates the company's ability to meet short-term liabilities. A company must optimize liquidity and profitability while performing its day-to-day business activities. Working capital management should contain these components of the balance sheet, e.g. debtors, inventories, accounts payable and effective use of cash for day-to-day business operations (Agha, 2014, pp. 374-375).

Proper working capital management ensures that the company increases its profitability. Effective working capital management is very important due to its significant effect on the profitability of the company, thus in the existence of a company in the market. If a firm minimizes its investment in current assets, the resulting funds can be invested in creating value from profitable projects, so it can increase the firm's growth opportunities and shareholder returns. The ability of financial managers to effectively and efficiently manage their receivables, inventories and accounts payable has a significant impact on business success as well as on profitability (Agha, 2014, p. 375).

Managing a firm's equity has been recognized as an important field in financial management. This field may include decisions on the amount and the combination of current assets and their financing. The working capital management process involves decisions on the various aspects of investing in monetary means, maintenance of a certain level of inventory, and the management of accounts receivable and payable.

The main purpose of working capital management is to learn and maintain an optimized balance between each working capital component. Business success depends heavily on the ability of financial managers to effectively manage accounts receivable, inventory and accounts payable. Firms can reduce financing costs and/or increase the funding available for expansion projects by minimizing the amount of investment tied up to current assets. Most of the time and effort of financial managers is allocated to bringing suboptimal levels of current assets and liabilities to optimal levels. Working capital management is one of the most important financial decisions in corporations. Optimal working capital management will increase the value of a corporation (Mousavi \& Jari, 2012, p. 141).

\subsection{The activity of commercial banks in Kosovo}

A fundamental characteristic of commercial banks is the mobilization of shortterm financial resources (short-term deposits) in order to place those assets in the short term. Commercial banks collect deposits and savings from the entire population and various cross-sectional entities. They are always committed to gathering the financial means and lending them (through various forms of lending), never forgetting that the lending interest and the risk they face are two challenges that maximally determine their lending terms. Characteristic of depository (commercial) banks is primarily the transformation of the short-term expiration date of the deposit (high liquidity) into the long-term (less liquid) asset, which directly affects their lack of liquidity and insufficient profitability (Halili, 2012, pp. 21-23). 
The activity of banks in the Republic of Kosovo is defined and regulated by the act of their establishment. In general, the banking system is very similar to the banking system in transition countries. Characteristic of the economic policy and thus of the economic development of the country, besides the different forms of achievements, is also the distribution of loans to clients, businesses and citizens in different quantities and different terms by commercial banks. Commercial banks, like other businesses, have profit as the main target. Bank profit is the difference between the income and expenses that are realized (Kryeziu, 2012, pp. 111-112).

In all countries, the banking system operates on two levels. The first level is identified by the functioning of the central bank while the second level is identified by the functioning of all other banks (Kryeziu, 2012, p. 113). In Kosovo, commercial banks or private banks have been conducting their financial activity since the last war in 1999, namely since 2000. Even before the war in Kosovo, various banks operated but they were of an outdated economic and political system.

Second level banks, or commercial banks, carry out their business activities in accordance with the law on banks and with the instructions from the Central Bank. In the market economy, currently in the territory of the Republic of Kosovo, the operating commercial banks and their subsidiaries or branches that have spread throughout Kosovo's territory are: Economic Bank, Bank for Business, NLB Pristina, ProCredit Bank, Raiffeisen Bank Kosovo J.S.C, National Commercial Bank, TEB Sh. A. Bank, Ziraat Bank, Turkiye Is Bankasi, and Komercijalna Banka ad Beograd (Kryeziu, 2012, p. 115).

Together, these banks have performed a valuable function for the economy of Kosovo, for investments in this economy and for citizens' deposits (Kryeziu, 2012, p. 116).

\section{Comparative analysis with the studies of other authors}

Financial investments in working capital affect firm performance. The principle of financial management stipulates that a high investment in working capital elements can lead to increased firm performance, increased annual turnover and firm profitability. On the contrary, firm performance decreases when investment in working capital is low. Previous research has shown that we expect firms' profitability and working capital to correlate positively in lower levels of working capital, but negatively in higher levels (Yeboah \& Yeboah, 2014, p. 296).

Sufficient working capital is always required to make it available to maintain the desired level of sales. A firm can be very profitable if it can make money from operations within the same operating cycle, otherwise the firm will have to borrow money to support ongoing working capital needs (Arshad \& Gondal, 2013, p. 384).

The relationship between working capital and profitability has also been explored by other researchers. Sharaf and Haddad (2015) in the study conducted on the relationship between working capital management and profitability in industrial companies in Amman, found a negative relationship between debt ratio and profitability. Moreover, the significant negative relationship between leverage measures and profitability implies that increasing external costs can be detrimental to companies' profitability. They also 
found that there is a positive relationship between bank size and profitability (Sharaf \& Haddad, 2015).

According to the authors Jakpar, Tinggi, Siang, Johari, Myint, \& Sadique (2017) in the study conducted in Malaysia, they explain that debt ratio (DR) significantly affects firm profitability. The result illustrates that there is an inverse relationship between the two variables, indicating that for any decrease in the debt ratio percentage will result in an increase in profit. These researchers also provide evidence that there is a positive relationship between firm profitability and firm size. Firm size is statistically significant in affecting firm profitability, suggesting that an increase in firm size increases profitability. Yeboah (2014) in a study conducted in Ghana on the impact of working capital on profitability, proved that debt ratio has an impact on bank profitability. This means that the lower cost of bank debt tends to increase the bank's profitability capacity, as banks are able to lend more to earn more interest income. They also found a negative relationship between bank size and profitability.

According to Okungu (2014) in the study conducted on the relationship between working capital management and profitability in the sugar industry in Kenya, he explained that an increase in debt ratio results in a decrease in profit. However, he proved that debt ratio had no significant impact on profitability. Additionally, in this study the researcher proved that firm size has an impact on profitability.

Rani \& Abreha (2017), in their study conducted on the impact of working capital on firm performance, found that there is a negative relationship between current ratio and profitability, and the current ratio has an impact on firms' profitability. They also proved that there is a negative relationship between debt ratio and profitability, and that debt ratio has a significant impact on firm performance. These researchers concluded that there is a positive relationship between profitability and bank size and that bank size has no impact on profitability.

According to Almazari, (2014) who conducted a study addressing working capital and profitability and the relationship between them, he found that the current ratio as a measure of liquidity has an impact on profitability. He also concluded that firm size has an impact on profitability, as an increase in firm increase will increase firm profitability. In his study, the researcher found that there is a relationship between debt ratio and profitability. Therefore, if debt ratio increases then profitability will decrease. In fact, debt financing affects the financial cost that will lead to a decrease in profitability.

\section{Methodology and specification of the econometric model}

This paper provides an empirical analysis of the impact of working capital on the profitability of commercial banks. The data used in this research are secondary and are taken from the annual reports of commercial banks and the reports of the Central Bank of Kosovo. From these data, some indicators will be calculated, such as return on assets, current ratio, debt ratio and the size of banks.

This research covers a period of 5 years and the data are analyzed through econometric models. Additionally, to assess the impact of working capital on the profitability of commercial banks in Kosovo linear trend analysis are used among the variables included in this study. 
The analysis includes data on seven commercial banks in Kosovo for a period of five years. The data are analyzed with the Stata program. To analyze the relationship between the dependent variables (ROA) and independent variables, this study has used regression analysis, fixed effect, random effect and Hausman Taylor Regression.

Table 3. Description of the variables included in the study

\begin{tabular}{|l|l|}
\hline Description of variables & Formula for calculation \\
\hline Return on assets & Net Profit / Total Assets \\
\hline The size of the bank & The natural logarithm of total assets \\
\hline Debt ratio & Total liabilities / Total assets \\
\hline Current ratio & Short Term Assets / Short Term Liabilities \\
\hline
\end{tabular}

Source: Author's data processing (2019)

\section{Dependent variable}

Various empirical studies on working capital management use return on assets (ROA) as a measure of firm profitability. Even in this study, the return on assets will be used as a measure of the profitability of commercial banks and will be taken as a dependent variable. Return on assets is a ratio that measures the effectiveness of the use of total assets in generating net profit. This ratio is widely used by financial analysts in measuring profitability.

\section{Independent variables}

Bank size is measured as the natural logarithm of total assets. Debt ratio over total assets estimates the firm's long-term solvency and shows the security margin for creditors. Practically this report shows debt participation in enterprise financing.

Current ratio is used as a liquidity criterion. Companies with more liquidity have more profitability. The current ratio is the direct proportion between short-term assets and short-term liabilities. This report measures the firm's ability to pay short-term liabilities at their maturity date (expiration of payment term). This ratio is actually a ratio of working capital.

The econometric model used in this study is a linear model which is specified as follows:

Return on assets $(\boldsymbol{R O A})=\beta_{0}+\beta_{1}$ Bank size $+\beta_{2}$ Debt ratio $+\beta_{3}$ Current ration $+\varepsilon$ From this model, the return on assets is the dependent variable. Bank size, debt ratio and current ratio are the independent variables, $\varepsilon$ refers to the error term, whereas $\beta 1, \beta 2$, and $\beta 3$ represent the model coefficients.

\section{Empirical results and study findings}

In the remainder of this study we will analyze the data for the variables included in this study, then through linear trends and econometric models some comparative analysis will be conducted between the results of this study and the findings of studies by other authors. 
Trend analysis was used to assess the relationship between return on assets, that is used in this study as a measure of profitability, and debt ratio, bank size, and current ratio. The data were obtained from the commercial banks' annual reports for a period of five years, and the elements calculated were return on assets, debt ratio, bank size, and current ratio. Then the ratio between return on assets with other variables for the seven commercial banks in Kosovo is analyzed.

Table 4: Return on assets for commercial banks in Kosovo

\begin{tabular}{|l|l|l|l|l|l|}
\hline Bank & $\mathbf{2 0 1 3}$ & $\mathbf{2 0 1 4}$ & $\mathbf{2 0 1 5}$ & $\mathbf{2 0 1 6}$ & $\mathbf{2 0 1 7}$ \\
\hline PCB & 2.03 & 1.81 & 2.32 & 2 & 2.32 \\
\hline TEB & 1.01 & 2.50 & 4.2 & 4.3 & 3.4 \\
\hline NLB & 0.07 & 1.17 & 1.82 & 2.23 & 2.43 \\
\hline BKT & 1.46 & 1.59 & 0.01 & 1.93 & 1.16 \\
\hline BE & 0.69 & 0.54 & 2.01 & 2.04 & 1.96 \\
\hline RBK & 2.18 & 2.0 & 2.2 & 1.93 & 1.95 \\
\hline BPB & 0.01 & 1.31 & 1.49 & 2.51 & 2.67 \\
\hline Total & 7.45 & 10.92 & 14.05 & 16.94 & 15.89 \\
\hline Sourc: & & & & \\
\hline
\end{tabular}

Source: Authors' calculations (2019)

The table above shows the data for return on assets for the commercial banks in Kosovo for the period 2013 - 2017. Taking 2013 into account, we can notice that ProCredit Bank is the bank with the highest return on assets (2.03), while in the other years 2014 - 2017, this bank ranks second in terms of return on assets.

In the period 2014 - 2017, according to the calculations conducted from banks' financial statements, it results that TEB Bank is very effective in utilizing total assets and generating net profit. The value of this ratio for TEB Bank in 2017 amounts to 3.4, which is a higher value compared to other banks.

Table 5 shows the data on the size of commercial banks in the banking sector in Kosovo. This is the first independent variable that is measured by the natural logarithm of total assets.

Table 5: Bank size for commercial banks in Kosovo

\begin{tabular}{|l|l|l|l|l|l|}
\hline Bank & $\mathbf{2 0 1 3}$ & $\mathbf{2 0 1 4}$ & $\mathbf{2 0 1 5}$ & $\mathbf{2 0 1 6}$ & $\mathbf{2 0 1 7}$ \\
\hline PCB & 5.89 & 5.90 & 5.89 & 5.90 & 5.90 \\
\hline TEB & 5.57 & 5.56 & 5.61 & 5.63 & 5.68 \\
\hline NLB & 5.66 & 5.66 & 5.65 & 5.70 & 5.76 \\
\hline BKT & 9.42 & 9.43 & 9.43 & 9.47 & 6.47 \\
\hline BE & 5.21 & 5.23 & 5.26 & 5.34 & 5.37 \\
\hline RBK & 5.86 & 5.88 & 5.91 & 5.94 & 5.95 \\
\hline BPB & 5.05 & 5.06 & 5.12 & 5.21 & 5.31 \\
\hline Total & 42.66 & 42.72 & 42.87 & 43.19 & 40.44 \\
\hline
\end{tabular}

Source: Authors' calculations (2019)

Based on the calculations made for the size of the bank, it turns out that the highest value of the natural logarithm of the total assets is that of Banka Kombtare Tregtare (National Commercial Bank). The average value of this indicator for this bank during the 
period 2013 - 2017 is 8.84, which indicates that this bank has a very effective management of total assets affecting the profitability of the bank. All the other commercial banks operating in Kosovo pay close attention to the management of their assets, therefore the average values of this indicator for these banks are approximately the same and all these values are positive. The cumulative average bank size for ProCredit Bank is 5.89, TEB Bank (5.61), NLB Bank (5.67), Banka Ekonomike (Economic Bank) (5.28), Raiffeisen Bank (5.90) and BpB (5.15).

Table 6: Debt ratio for commercial banks in Kosovo

\begin{tabular}{|l|l|l|l|l|l|}
\hline Bank & $\mathbf{2 0 1 3}$ & $\mathbf{2 0 1 4}$ & $\mathbf{2 0 1 5}$ & $\mathbf{2 0 1 6}$ & $\mathbf{2 0 1 7}$ \\
\hline PCB & 0.87 & 0.88 & 0.88 & 0.88 & 0.87 \\
\hline TEB & 0.92 & 0.90 & 0.87 & 0.83 & 0.81 \\
\hline NLB & 0.90 & 0.88 & 0.89 & 0.89 & 0.88 \\
\hline BKT & 0.91 & 0.91 & 0.89 & 0.88 & 0.89 \\
\hline BE & 0.92 & 0.92 & 0.90 & 0.90 & 0.89 \\
\hline RBK & 0.84 & 0.83 & 0.84 & 0.86 & 0.86 \\
\hline BPB & 0.92 & 0.91 & 0.91 & 0.90 & 0.90 \\
\hline Total & 6.28 & 10.72 & 6.18 & 6.14 & 6.1 \\
\hline
\end{tabular}

Source: Authors' calculations (2019)

The table above presents data on the debt ratio for commercial banks in Kosovo over the period 2013 - 2017. Based on these results, we can notice that all the commercial banks included in this study have a similar debt ratio value for this five-year period. The cumulative average value of this ratio is as follows: PCB (0.87), TEB (0.86), NLB (0.88), BKT (0.89), BE (0.90), RBK (0.84) and BpB (0.90). So, as we can see the highest value of debt ratio is at Banka Ekonomike (Economic Bank) and Banka Private e Biznesit (Private Business Bank).

Based on this, it is worth noting that all these banks have similar average values, therefore are considered as banks with a long-term positive solvency, which means that these banks are able to settle all liabilities from depositors and have a level high security margin as creditors.

The following table presents the results of the current ratio for all commercial banks in Kosovo covering the analyzed period 2013 - 2017. The calculation of this ratio is made according to the formula: short term assets / short term liabilities. Through these results we will see how liquid banks are in settling their liabilities to depositors, because a high degree of bank liquidity will also affect the profitability of these commercial banks.

Table 7: Current ratio on commercial banks in Kosovo

\begin{tabular}{|l|l|l|l|l|l|}
\hline Bank & $\mathbf{2 0 1 3}$ & $\mathbf{2 0 1 4}$ & $\mathbf{2 0 1 5}$ & $\mathbf{2 0 1 6}$ & $\mathbf{2 0 1 7}$ \\
\hline PCB & 0.86 & 0.97 & 0.98 & 0.90 & 0.94 \\
\hline TEB & 1.11 & 1.12 & 1.13 & 1.14 & 1.17 \\
\hline NLB & 0.95 & 0.97 & 0.95 & 0.97 & 0.97 \\
\hline BKT & 0.59 & 0.59 & 0.64 & 0.67 & 0.45 \\
\hline BE & 0.94 & 0.85 & 0.92 & 0.94 & 0.96 \\
\hline RBK & 1.01 & 0.98 & 0.88 & 0.92 & 0.90 \\
\hline
\end{tabular}




\begin{tabular}{|l|l|l|l|l|l|}
\hline BPB & 0.26 & 0.29 & 0.29 & 0.27 & 0.30 \\
\hline Total & 5.72 & 5.77 & 5.79 & 5.81 & 5.69 \\
\hline
\end{tabular}

Source: Authors' calculations (2019)

The results in Table 7 show that the majority of the commercial banks have a positive current ratio. The highest cumulative average value is held by TEB Bank (1.13) and NLB Bank (0.96). However, other banks also have a positive average value similar to TEB and NLB.

Through the analyzed period (2013 - 2017), Banka Kombëtare Tregtare (National Commercial Bank) (0.58) and Banka Private e Biznesit (Private Business Bank) (0.28) have the lowest level of liquidity compared to the other commercial banks included in this analysis. Based on these results, we note that all commercial banks in Kosovo are very cautious about liquidity because a good management of this working capital ratio will positively affect the profitability of commercial banks in Kosovo.

The following table summarizes all the results of the econometric models. To test the validity of the hypotheses presented we have applied several statistical tests such as: linear regression, fixed effect, random effect, and Hausman Taylor Regression.

Table 8. Results of regression analysis, fixed effect, random effect, Hausman Taylor Regression, for the variables included in the study

\begin{tabular}{|l|l|l|l|l|}
\hline Variables & $\begin{array}{l}\text { Linear } \\
\text { Regression }\end{array}$ & Fixed-Effect & Random Effect & $\begin{array}{l}\text { Hausman } \\
\text { Taylor } \\
\text { Regression }\end{array}$ \\
\hline ROA & - & - & - & - \\
\hline Bank size & 0.1055906 & 0.2123413 & 0.0494681 & 0.029471 \\
& 0.001 & 0.000 & 0.000 & 0.007 \\
\hline Current ratio & 0.2986025 & 0.966053 & 0.2636819 & 0.1264814 \\
& 0.008 & 0.003 & 0.000 & 0.001 \\
\hline Debt ratio & -1.95567 & -2.05694 & -2.68744 & -2.90343 \\
& 0.001 & 0.001 & 0.000 & 0.000 \\
\hline
\end{tabular}

Source: Authors' calculations (2019)

H1: There is a significant relationship between the bank size and the profitability of commercial banks in Kosovo.

The coefficient of the bank size variable is positive; therefore, bank size has a positive impact on the profitability of commercial banks in Kosovo. Significance value of bank size is significant at 0.05 , thus confirming the first alternative hypothesis which argues for a significant relationship between the bank size and the profitability of commercial banks in Kosovo.

According to the results of the Hausman Taylor Regression we can conclude that a 1\% increase in the size of the bank will affect an increase in return on assets by $0.02 \%$. This implies that the continuous increase of the bank's assets also affects the increase of return on investment from these assets. In the following figure we will analyze what is 
the trend between the bank size and the return on assets for the commercial banks in Kosovo, which covers the period 2013 - 2017.

As can be seen from Figure 1, there is a positive relationship between bank size and return on assets. There is a positive linear trend between these two variables with a high coefficient of determination at $87.29 \%$. This coefficient indicates that we have a very high explanatory level between these two variables.

The value of the cumulative average trend is 27.04, a value which, if compared to the analyzed period, shows that the positive trend is from 2013 to 2017. Therefore, we can observe that the continuous increase in the size of commercial banks has affected the increase in return on assets from 7.45 to 16.94, while a slight decrease in return on assets can be observed only in 2017, from 16.94 to 15.89. Based on this comparative analysis, we can conclude that the continuous increase in bank size has led to an increase in the profitability of the commercial banks in Kosovo.

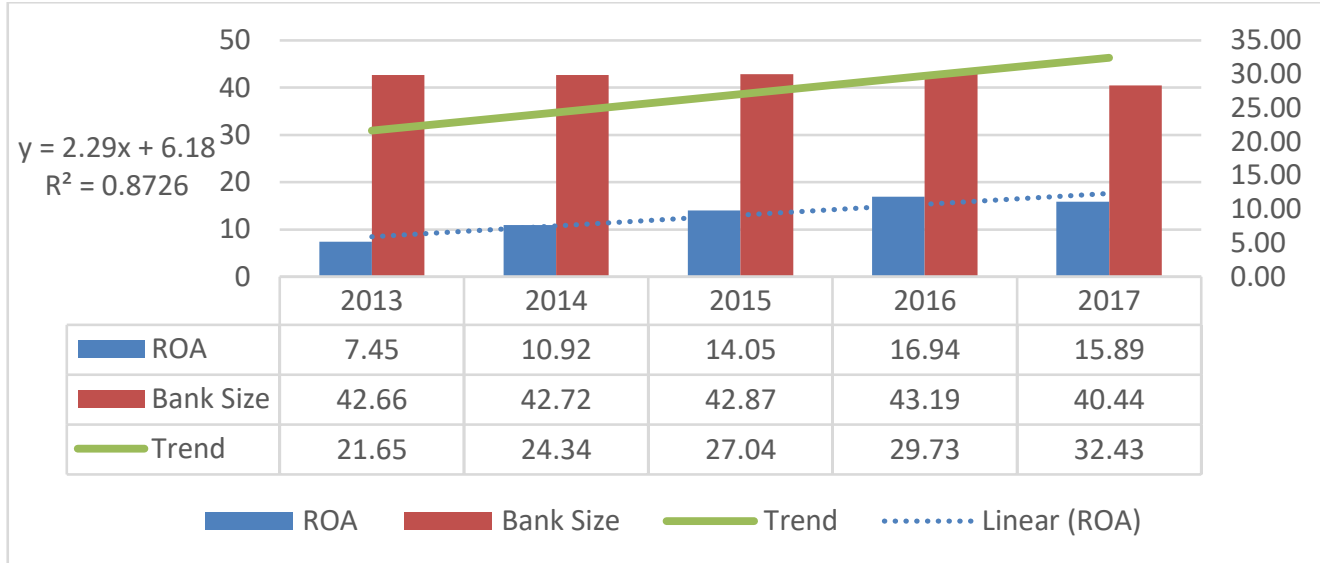

Figure 1. The linear trend between bank size and return on assets for commercial banks in Kosovo Source: Authors' calculations (2019)

This econometric result is consistent with the results of these authors:

Sharaf \& Haddad (2015), in the study of the relationship between working capital management and profitability in industrial companies in Amman, found that there is a positive relationship between firm size and profitability.

Jakpar, Tinggi, Siang, Johari, Myint \& Sadique (2017), in the study conducted in Malaysia on working capital management and profitability, also provide empirical evidence that there is a positive relationship between firm profitability and firm size. Firm size is statistically significant and affects firm profitability, suggesting that an increase in firm size increases profitability.

Yeboah (2014) in a study conducted in Ghana on the impact of working capital on profitability, found a negative relationship between bank size and profitability. Mathuva (2010), in his study of the impact of working capital management components on profitability, concluded that there is a positive relationship between firm size and profitability, and firm size has an impact on profitability. 
Almazari (2014), in his study on the relationship between working capital and profitability, concluded that firm size has an impact on profitability because an increase in firm size will increase firm profitability.

This empirical result contradicts the results of other authors:

Yakubu, Alhassan, \& Fusein (2017), in a study conducted in Ghana, regarding the impact of working capital management on firm performance, found that firm size and firm performance are negatively correlated and not significant; hence, firm size has no impact on firm performance.

Okungu (2014), in a study conducted on the relationship between working capital management and profitability in the sugar industry in Kenya, proved that firm size has no impact on profitability.

Rani \& Abreha (2017), in their study on the impact of working capital on firm performance, concluded that there is no positive relationship between profitability and bank size and that bank size has no impact on profitability.

H2: Current ratio has a significant impact on the profitability of commercial banks in Kosovo.

The coefficient of current ratio is positive, so there is a positive relationship between current ratio and profitability. Significance value is within the level of statistical significance $\mathrm{P}$-value $=0.05$; so, the second alternative hypothesis is accepted, which postulates that current ratio has a significant impact on the profitability of banks. If we increase the current ratio by $1 \%$, this means that we will have an increase in return on assets by $0.12 \%$. Thus, the more liquid the commercial banks are, the more profitable they will be, creating a stable financial stability in the banking system.

These empirical findings are consistent with the results of these studies:

Rani \& Abreha (2017), in a study conducted on the impact of working capital on firm performance, found that there is a positive relationship between current ratio and profitability, and current ratio has an impact on firms profitability.

Yakubu, Alhassan, \& Fusein (2017), in a study conducted in Ghana regarding the impact of working capital management on firms' performance, proved that the coefficient of current ratio is positive and current ratio is statistically significant.

Almazari (2014) in his study of the relationship between working capital and profitability, found that the current ratio as a measure of liquidity has an impact on profitability.

These empirical findings contradict the results of these studies:

Agha (2014) in a study conducted on the impact of working capital management on the profitability of Glaxo Smith Kline pharmaceutical company in Pakistan, found that current report has no impact on profitability.

Afeef (2011) in a study conducted on the impact of working capital management on the profitability of small and medium-sized enterprises in Pakistan, found that there is no significant relationship between profitability and current ratio, and that current ratio does not have an impact on profitability.

Based on the data presented in the figure above, we can observe that there is a positive growth trend between the two variables included in this empirical analysis. The cumulative average trend value between current ratio and return on assets is 9.24, which results in a positive upward trend for the analyzed period 2013 - 2017.

From 2013 to 2016, we have a continuous increase of current ratio, from 5.72 to 5.81, which is also associated with the increase of profitability of the commercial banks in 
Kosovo. Whereas, it is worth noting that in 2017, we have a modest decline in current ratio, from 5.81 to 5.69, which has also led to a decrease in return on assets. Based on this comparative analysis, we can conclude that the more liquid the commercial banks are, the greater their profitability. This also confirms the validity of the second alternative hypothesis, that there is a significant relationship between current ratio and return on assets.

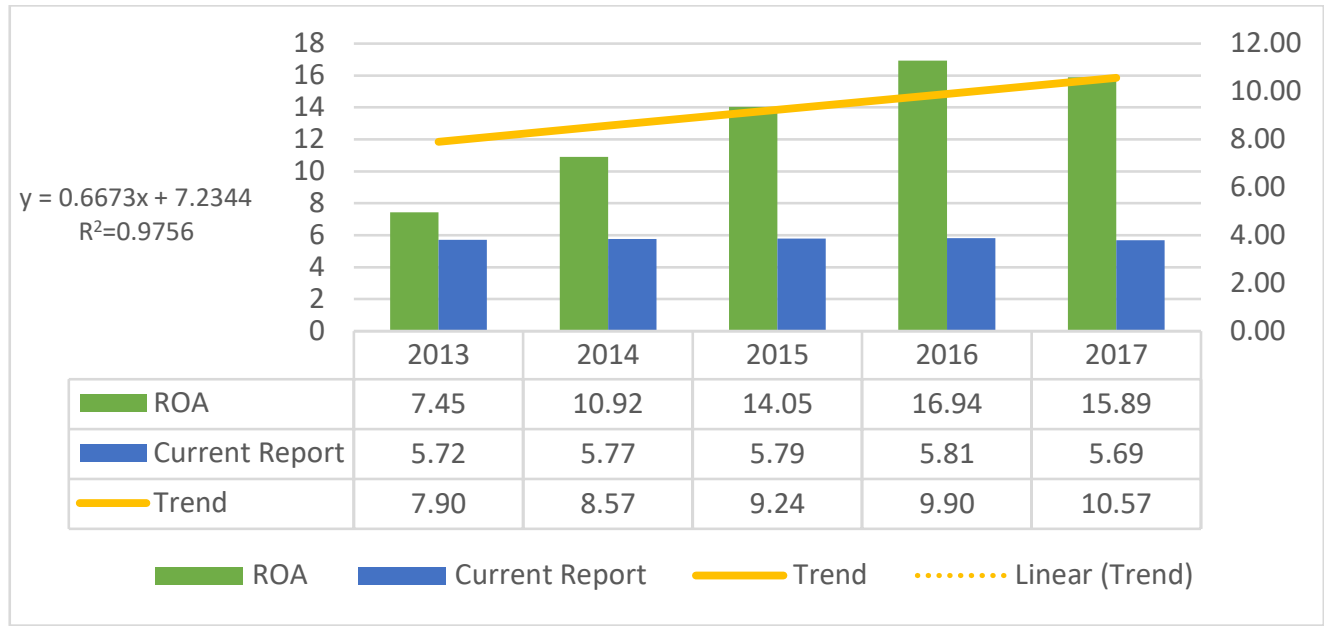

Figure 2. The linear trend between current ratio and return on assets for the commercial banks in Kosovo Source: Authors' calculations (2019)

H3: Debt ratio has a significant impact on the profitability of commercial banks in Kosovo. The coefficient of debt ratio is negative, indicating that we have an inverse relationship between return on assets and debt ratio. All model parameters are within the confidence interval, $\mathrm{p}$-value $=0.05$. This indicates that the third alternative hypothesis is confirmed, which postulates that debt ratio has a significant impact on the profitability of commercial banks in Kosovo. If we get a 1\% increase in debt ratio, then return on assets will decrease by $2.9 \%$.

Such a result makes a logical interpretation, given that if banks continuously increase their debt financing, this implies that there is also an increase in the interest rate on deposits, which will then result in a greater financing cost, which directly impacts on the reduction of banks' profit. Therefore, it is very important that commercial banks put great attention to the credit-to-deposit ratio, interest rates, and their concentration. 


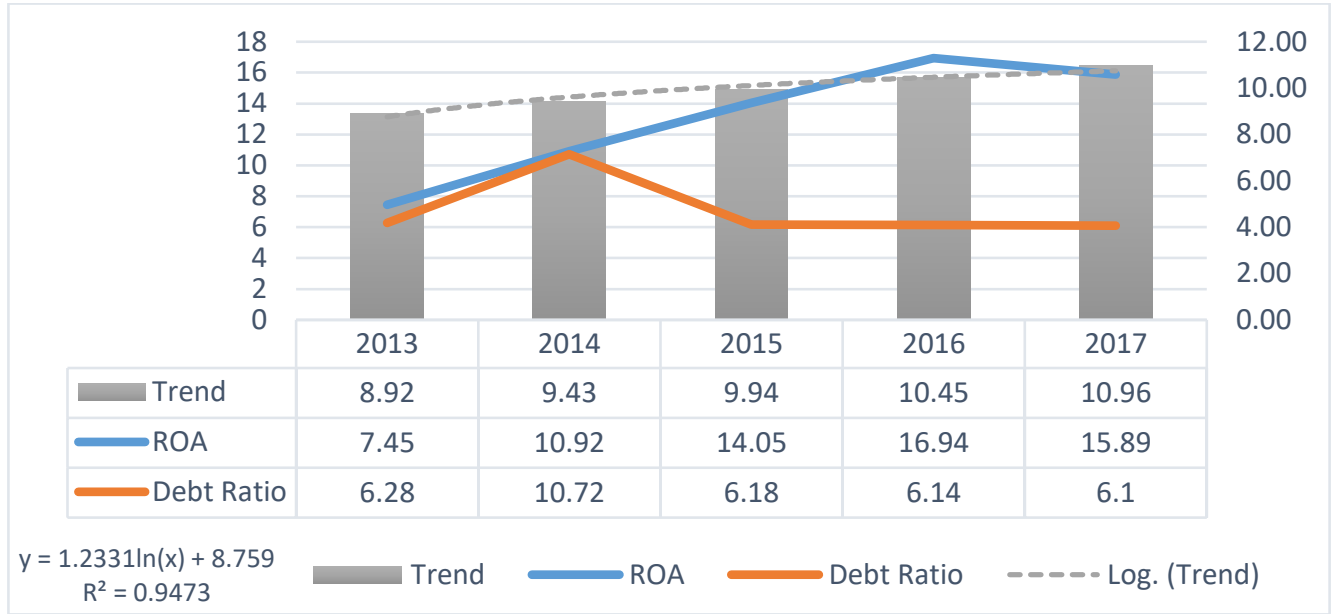

Figure 3. The logarithmic trend between the debt ratio and the return on assets for commercial banks in Kosovo Source: Authors' calculations (2019)

Based on the above figure, we can see that debt ratio has a significant impact on the profitability of commercial banks in Kosovo and this ratio between these two variables is inverse. An increase in debt causes a decrease in the profitability of banks and a decrease in debt causes an increase in the profitability of commercial banks.

According to the data, the analyzed period 2013 - 2017 is characterized by a sharp decline in debt ratio, especially from 2014 to 2017. In this time period, we have had a decrease in debt ratio from $10.72 \%$ to $6.10 \%$, a decrease which has led to an increase in return on assets from $10.92 \%$ to $16.94 \%$. Whereas, in 2017 we have a decrease in return on assets from $16.94 \%$ to $15.89 \%$. Therefore, it is worth noting that for this analyzed time period, the decline in debt ratio has caused an increase in return on assets for the commercial banks in Kosovo.

The average value of the cumulative trend between debt ratio and return on assets is 9.94, indicating a positive upward trend between these two variables. The value of the coefficient of determination is $94.73 \%$, indicating a very high explanatory level between debt ratio and return on assets.

These empirical findings are consistent with the results of these studies:

Sharaf \& Haddad, (2015) in a study on the relationship between working capital management and profitability in industrial companies in Amman, found that there is a negative relationship between debt ratio and profitability. Moreover, the significant negative relationship between financial leverage and profitability implies that increasing external costs can be detrimental to companies' profitability.

Jakpar, Tinggi, Siang, Johari, Myint, \& Sadique, (2017) in a study conducted in Malaysia, explain that debt ratio (DR) significantly affects firm profitability. The result illustrates that there is an inverse relationship between the two variables, indicating that any decrease in the debt ratio percentage will result in an increase in profit.

Yeboah (2014) in a study conducted in Ghana on the impact of working capital on profitability, proved that debt ratio has an impact on bank profitability. This means that 
the lower cost of bank debt tends to increase the bank's profitability capacity as banks are able to lend more to earn more interest income.

Rani \& Abreha (2017), in a study on the impact of working capital on firm performance, found that there is a negative relationship between debt ratio and profitability, and that debt ratio has a significant impact on firm performance.

Mathuva (2010), in a study conducted on the impact of working capital management components on profitability, proved that there is a negative relationship between debt ratio and profitability, and that debt ratio has an impact on the profitability of firms.

The results of this study are in contrast to the results of Okungu, (2014), who, in the study conducted on the relationship of working capital management and profitability in the sugar industry in Kenya, explained that an increase in debt ratio results in a decrease in profitability. However, he proved that debt ratio had no significant impact on profitability.

\section{Conclusions}

The importance of working capital is uncontested. Working capital management is considered one of the most important functions of bank management. Capital is a very important factor for maintaining liquidity, banks survival, solvency and profitability. All organizations, whether profit-oriented or not, regardless of the nature and size of the business, require a certain amount of working capital.

Working capital management is considered an important area of financial management, which includes decisions on the amount and combination of current assets and their financing. Working capital meets the financial requirements of banks; therefore, these requirements determine the banks' liquidity and profitability. Most commercial banks have a large amount of cash to invest in working capital, given that banks with an optimal level of working capital maximize their value.

Profitability is one of the most important issues that bank management should consider as the most important task. Profitability can increase if banks manage their capital by working in a more efficient way; thus, capital management plays an important role in improving banks' profitability. Decisions on working capital ought to always be respected in the financial decision making of each bank, since optimal working capital management will contribute positively to the bank's value creation.

This study found that there is a negative relationship between debt ratio and profitability; therefore, as debt increases there will be a decrease in profitability. This means that commercial banks will not depend on debt financing to pay their liabilities, and debt financing affects the financial cost that will lead to lower profitability.

This study also found that bank size has an impact on the profitability of commercial banks in Kosovo. As the size of a bank increases, profitability will increase and large banks will have a greater profit power than smaller banks - this is confirmed in this study since bank size and profitability are positively correlated.

Current ratio is the most important measure of liquidity affecting profitability. Contrary to the results of some other studies, this study found that current ratio has a significant impact on the profitability of commercial banks in Kosovo. 
A recommendation for all banks would be to invest as much as possible in working capital as financial working capital affects the bank's profitability. This means that a high investment in working capital elements can lead to an increase in the bank's profitability, while its profitability decreases when investment in working capital is low.

Banks also need to manage working capital efficiently because efficient working capital management increases the value of the firm and helps to meet liquidity and profitability objectives. With efficient working capital management banks will also increase their investment opportunities, and will have lower financial costs.

\section{References}

Afeef, M. (2011, December). Analyzing the Impact of Working Capital Management on the Profitability of SME's in Pakistan. International Journal of Business and Social Science , 2, 173.

Agha, H. (2014). Impact of working capital management on profitability. Europian Scientific Journal, 10, 381.

Almazari, A. A. (2014). The Relationship between Working Capital Management and Profitability: Evidence from Saudi Cement Companies. British Journal of Economics, Management \& Trade, 4(1), 146-157.

Arshad, Z., \& Gondal, M. Y. (2013, June). Impact of working capital management on profitability a case of the Pakisatn cement industry. Interdiciplinary Journal of Contemporary Research in Bussines, 5, 384.

Gill, A., Biger, N., \& Mathur, N. (2010, July 31). The Relationship Between Working Capital Management And Profitability: Evidence From The United States. Business and Economics Journal, 2.

Halili, T. (2012). Bankat dhe menaxbimi i bankave. Prishtinë: Universiteti AAB RIINVEST.

Husaria, A. (2015). The effect of working capital management on firms profitability: comparative study on Middle East and West Europe companies. Universidade Lusófona do Porto , Faculdade de Ciências Económicas, Sociais e da Empresa . Porto: Universidade Lusófona do Porto - recil.ulusofona.pt.

Jakpar, S., Tinggi, M., Siang, T., Johari, A., Myint , K., \& Sadique, M. (2017). Working Capital Management and Profitability: Evidence from Manufacturing Sector in Malaysia. Journal of Business \& Financial Affairs, 6(2).

Kryeziu, R. (2012). Sistemi bankar e kereditor dhe ndikimi i tij në z̧billimin ekonomik. Prishtinë: Universiteti AAB, aab-edu.net.

Mandiefe, S. P. (2016). How Working Capital Affects the Profitability of Commercial Banks: Case of Afriland Cameroon. Arabian Journal of Business and Management Review, 6(6).

Mbawuni, J., Mbawuni, M. H., \& Nimako, S. G. (2016). The Impact of Working Capital Management on Profitability of Petroleum Retail Firms: Empirical Evidence from Ghana. International Journal of Economics and Finance, 8(1916-971X), 49.

Mousavi, Z., \& Jari, A. (2012, January). The Relationship between Working Capital Management and Firm Performance:Evidence from Iran. International Journal of Humanities and Social Science, 2, 141.

Okungu, D. H. (2014). The relationship between working capital management and profitability of sugar producing companies in Kenya. University of Nairobi, Bussines Administration. Kenya: University of Nairobi.

Rani, D. S., \& Abreha, H. A. (2017). The impact of working capital management on firm`s performance (A Case Study on Endowment Fund for Rehabilitation of Tigray (E.F.F.O.R.T) Manufacturing Companies). International Journal of Commerce and Management Research, 3(9).

Sharaf, R. F., \& Haddad, F. S. (2015). The Relationship between Working Capital Management and Profitability for Industrial Companies Listed in Amman Stock Exchange. Jordan Journal of Business Administration, 11, 510.

Yakubu, I. N., Alhassan, M. M., \& Fusein, A.-A. (2017, March). The impact of working capital management on corporate performance: evidence from listed non-financial firms in Ghana. European Journal of Accounting, Auditing and Finance Research, 5(3), 68-75.

Yeboah, B., \& Yeboah, M. (2014, September). The Effect of Working Capital Management of Ghana Banks on Profitability: Panel Approach. International Journal of Business and Social Science , 5(10). 